\title{
Competition and microfinance institutions' performance: evidence from India
}

\author{
Hailu Abebe Wondirad
}

\begin{abstract}
This paper empirically examines whether competition (measured by using the new measure of competition, the Boone Indicator) moderates the relationship between Microfinance Institutions' (MFIs) social and financial performances using data from 183 Indian MFls over the period 2005-2014.

The findings indicate that MFIs' social and financial performances have a positive significant relationship. Moreover, the form of the relationship is both lead-lag and cotemporal. The Indian microfinance market was very competitive over the period 2005-2014. The empirical findings show that competition positively moderates the relationship between MFIs' social and financial performances. More precisely, the empirical analysis provides evidence that the association between MFIs' depth of outreach and operational self-sufficiency is conditional upon competition. These results suggest that in a competitive market, the more MFI deepen their depth of outreach, the higher contribution it has to their operational self-sufficiency.
\end{abstract}

Keywords: Microfinance, Competition, Boone Indicator, Social performance, Financial performance

\section{Introduction}

Microfinance is the provision of financial service to the poor and low-income people (Mersland, 2011). These financial services include savings, credit, insurance, and payment services (Ledgerwood, 1999). Microfinance Institutions (henceforth, MFIs) have unique features (i.e. in the form of product or service types, and lending methodologies) that distinguish them from formal banking institutions (Quayes, 2012). MFIs are created to fill the market segment that has long been unveiled by the conventional banking sector (Vanroose \& D’Espallier, 2013).

In the recent decade, the Microfinance industry has been growing rapidly in developing countries (Assefa, Hermes, \& Meesters, 2013; Kar, 2016), and has gotten high recognitions from international actors, donors, and governments (Olsen, 2010). The assets of the industry increased from 4 billion to 7 billion from 2006 to 2008 (Littlefield \& Kneiding, 2009) and demonstrated a growth rate of $25 \%$ per year from 2004 to 2008 (Servet, 2011). The total clients served by the sector were also reached over 205.3 million in 2012 (Maes \& Reed, 2012).

Correspondence: hailat.abebe@gmail.com

College of Business and Economics, Bahir Dar University, Bahir Dar, Ethiopia
The increasing inflow of investment into microfinance is partly because the international community believes MFIs have an institutional foundation that fosters local economic development, creates jobs and empowers women (Gutierrez-Nieto, Serrano-Cinca, \& Molinero, 2007). Commercialization, accompanied by a huge flow of investment, is the main drivers of microfinance's evolution and makes it the hub of the potential business opportunity that spurring many institutions to change their ownership from not-for-profit to for-profit (eg. Bancosol Bolivia, Equity in Kenya, ACLEDA in Cambodia, SKS Microfinance in India, and Compartamos in Mexico) (Servet, 2011). But studies have been presented that microfinance is not drifted from their mission of serving the low-income people (Mersland \& Strøm, 2010).

Although MFIs are propagating as banks for the poor, some MFIs address wealthier clients and profitable business segments. MFIs business model is different in terms of ownership, lending methodology, portfolio size, goals, and target market. The impact of the growing trend of commercialization has recently been part of microfinance study (for example Assefa et al., 2013; Cull, Demirgüç-Kunt, \& Morduch, 2011; Fombrun, Gardberg, \& Barnett, 2000; Freeman, 2010; Woller, 2002) Most of 
these studies have documented both positive and negative effects of competition on MFI's performance or operation in general. The claim of mission drift is also emanating from the exigent debate of commercialization and MFIs' mission. The root of the debate is that when competition increased, MFIs may shrink from their social mission and then starts striving for financial returns. Altogether, in line with mission drift claims, competition may moderate the association between social and financial performance. Therefore, to prove the existence of this fact, this paper examines the effect of competition on the relationship between social and financial performance by focusing on Indian MFIs.

This paper is organized as follows: In Section 2, the statement of the problem is discussed. Section 3 highlights the microfinance practices of India. Section 4 presents a literature review of the study. In section 5, the methodology and data of the paper are discussed. Section 6 describes the analysis of the results. Section 7 presents conclusions along with some recommendations. Finally, in section 8 of this paper, the practical implication(s) for MFIsare discussed.

\section{Statement of the problem}

Because of the lack of infrastructure and smaller portfolio sizes, providing financial services to the unbanked poor people, are very expensive and challenging. As a result, the financial institution serving this segment of the population is considered as socially motivated MFI and has defined social goals. However, whether MFIs emphasize on social aspects or financial aspects has been part of a continuing debate (Conning, 1999). In a competitive environment, being a socially responsible institution has a financial cost which in turn impends financial performance (Fombrun et al., 2000; Freeman, 2010). Firms participating in social development activities faced lower stock value as compared to the average (Vance, 2011), and then experienced lower financial performance relative to competitors in the industry (Klein \& Dawar, 2004). In line with this, Cull, Demirgüç-Kunt, and Morduch (2008) and Hermes, Lensink, and Meesters (2011) find a trade-off relationship between financial sustainability and outreach.

On the contrary, the firm's participation in social development activities helps to retain customers and increases sales volume where positively contributed to financial performance (Ruf, Muralidhar, Brown, Janney, \& Paul, 2001). In microfinance, Montgomery and Weiss (2011), and Quayes (2012) find evidence that supports this theory; in such a way that outreach has a positive significant relationship with financial performance.

Recently, a double bottom line approach ${ }^{1}$ has become popular in microfinance. MFIs have also been started

\footnotetext{
${ }^{1}$ Double bottom line objective is refers to MFIs' social outreach and financial sustainability (Morduch, 1999).
}

pursuing a balance between social and financial performance (Ngo, 2015). Rating organizations have already started rating MFIs based on the ability to pursue their double bottom line objectives (Gutiérrez-Nieto, SerranoCinca, \& Molinero, 2009). On top of that, the rapid evolution of Microfinance and its commercialization induced intense competition (Assefa et al., 2013; Woller, 2002). As competition increased, dealing with double bottom line objectives and achieving it simultaneously requires a strategic decision that reconciles the defined mission, and also be challenging. Consequently, increasing competition creates frustration that may compromise the MFIs' social mission. It has been witnessed that commercialized MFIs provide four times larger loans, then non-commercialized MFIs (Cull et al., 2011), which shows that they might have abandoned their marginalized borrowers. Through increasing clients' loan burden and deteriorating repayment performance, the competition also threatens MFIs' financial performance (Assefa et al., 2013).

Theoretically, there are two different views. On the one hand, the competition-fragility theory that states, lack of competition in the market develop rent-seeking behaviors among firms (Boyd \& De Nicolo, 2005). In such a market, MFIs are price setter rather than price takers. Although this theory points out that clients became a victim of the rentseeking behavior of MFIs, the state of mission drift could not be determined. On the other hand, the competitionstability theory views firms as price takers (Beck, 2008). The market is offering an affordable price to customers. According to this theory, the competition allows clients to have strong barraging power on the price of a loan and to get a required loan amount. However, the sustainability of MFIs doesn't exactly define. Competition-fragility theory has a profit motive, whereas, competition-stability theory recognized financial accesses at an affordable price. Thus, theories are not rationalized the impacts of competition on the relationship between MFIs' social and financial performance. Altogether, in the financial market where there is a high competition, the relationship between social and financial performances of microfinance institutions is inferred.

Thus, from the above discussion, it can be thought out that in a highly competitive market, MFI focuses on a social mission that may experience lower financial performance or vice-versa. It means competition may influence the relationship between social and financial performance. In microfinance, understanding the characteristics of this market force (competition) and responding accordingly to it is vital to offer financial service permanently to the poor people and keep MFIs' sustainability in the long run (Vogelgesang, 2003).

Although some studies examined the effect of competition on MFIs' performance, the moderating effect of competition on the link between social and financial 
performances hasn't been studied. Therefore, by considering these gaps, this study tried to analyze the following two research questions:

1) What is the relationship between MFIs' social and financial performance?

2) Does competition has a moderating effect on the relationship between MFIs' social and financial performance?

The overall objective of this research is to analyze the moderating effect of competition on the relationship between MFIs' social and financial performance. Specifically, the research aims to identify the effect of competition on the link between depth and breadth of outreach, and Operational Self-Sufficiency (OSS) and Return on Asset (ROA) links.

\section{Microfinance in India}

The development and features of the Indian microfinance sector are discussed below. Microfinance has long been considered as instruments to provide financial services to the marginalized poor segment of the population in India.

The history of microfinance in India goes back to the 1970s when the first form of microfinance, Self Employed Women's Association (SEWA), has established to provide financial services to poor women. In 1969 industrialization policy of India shifted its attention towards designing a new lending approach to the agricultural sector and rural poor (Burgess \& Pande, 2003.) This brought a downfall to informal credit operated by moneylenders, which accounts for more than half of the household credit in the 1970s (Shah, Rao, \& Shankar, 2007). In early 19th India has long been recognized as a country where a large number of unbanked rural poor people found. To change this by providing access to finance to the remotely found rural poor people, microfinance is considered as a promising instrument to bring sustainable rural development.

Therefore, in the 1970s and 1980s, the government has designed the Integrated Rural Development Program (IRDP) with the mission to subsidized agricultural credit and bring livelihood improvement (Taylor, 2001). This program has been an opportunity for rural poor to experience the formal financial sector. Later, in 1972, the SelfEmployed Women's Association of India (SEWA) established and started providing financial services and led a path for the establishment of SEWA Bank (Datta, 2003).

After a decade of its first movement, another form of microfinance, Self Help Groups (SHGs) has emerged in India and became popular still now. Then, NonGovernmental Organizations (NGOs) and other community development institutions have been joined the industry and became major players in the sector.
Generally, the historical evolution of microfinance growth in India has divided into two stages. The first stage was the one motivated and supported by NGOs and other development organizations by offering microcredit services. The second phase considered as a "microfinance movement" where formal financial firms have entered into the microfinance market to provide financial services to the unbanked poor people. In the "microfinance movement" the forms or legal status of institutions and their financial products and services have diversified. It is also considered as the transformation from mere credit age to all-rounded financial services age. Currently, Commercial Bank, Non-Bank Financial Institutions (NBFI), Rural Bank, Credit Union, and NGOs are the well-known forms of microfinance institutions operating in India that providing credit, saving, remittance, financial training (Guha, 2007). The Indian microfinance sector is dominated by NBFIs, has an $80 \%$ market share (Etzensperger, 2013).

As indicated above the Indian microfinance operation has been leading by the different forms of institutions. However, their services delivery model can be categorized into two main delivery models: SHG and MFI model. The latter is the most dominant model in the country. The MFI model provides a range of lending methodologies such as joint liability groups, Grameen, and individual banking.

From 2005 to 2010, the Indian microfinance industry has strongly been grown (Kar, 2016). The clients' demand for the loan and huge flow of investment are the diver factors of the high growth of the industry. However, later, an unprecedented crisis affected the promising growth of the Indian microfinance industry.

The crisis happened in Andhra Pradesh, a southern state of India. Although Andhra Pradesh was the place where the crisis began before the watershed the state was considered as the hub of microfinance, and many NGO driven MFIs where found. In 2006 when the sector entered into crisis, in Krishna district of Andhra Pradesh, the borrowers turned into demonstration and violent to claim back their fixed asset seized as collateral. In Andhra Pradesh, as compared to other regions, averagely a household owe loans from nine MFIs (India Report 2010). Because this state placed the sector as a priority sector to tackle poverty and received support from the World Bank, the sector has been highly expanded, and overlapping became the main feature of Indian MFIs (Taylor, 2001). Until recently, because of the availability of loans from competitive sources, the sector represents a low repayment rate.

The crisis exacerbate when around 200 suicides were linked to microfinance institutions. Due to the crisis, the repayment rate of the sector dropped down to $10 \%$. On top of that, a very high default rate, unethical loan 
collection practices, and high-interest rate (25\% -40\%) become the characteristics of the Indian microfinance sector (Ghate, 2007 and Sharma, 2006). By the time, 40\% of the residents of the state of Andhra Pradesh had MFIs' loan (Mader, 2013). Altogether puts 82\% of households of the district indebted. Consequently, the government has taken action by closing around 50 MFIs (Mader, 2013).

After the crisis the microfinance industry of India continued to demonstrate high growth. However, commercialization and aggressive expansion of MFIs intensify the competition in the sector. The crisis and the entrance of MFIs into the stock market are considered as the main driver of commercialization in the Indian microfinance sector.

Following Compartamos (Mexican MFI), Indian MFI, SKS entered into the initial public offering and raised around \$350 million. Due to the large commercial fund injected into the sector, the loan portfolio has been substantially increased and exacerbate the trend of commercialization.

On the other hand, the neo-liberal economic reform and commercial funding, have been taking as another pushing factor of commercialization in the microfinance sector of India (Bateman, 2010; Taylor, 2001 and Wichterich, 2012). Commercial funding affects MFIs to change their source of funds from loans to share capital by entering into the capital market (Mader, 2013; Taylor, 2001).

Moreover, the legal framework of the Indian microfinance sector is also responsible for the high growth of the commercialization of microfinance. In India, only formal financial Institutions are allowed to raise equity capital and mobilize public deposits. Hence, NGOs, SHGs, and other semi-formal money lenders forced to change their legal status into NBFIs and banks which then leads to shifting from their social mission to finance-oriented (Guha, 2013).

As evidenced above, commercialization becomes the main feature of the Indian microfinance sector. This commercialization leads to competition and market saturation (Mader, 2013). Competition, in turn, causes overindebtedness in the sector. Later in 2010, the government of India introduced interest caps. Nowadays, the microfinance market of India undergone trough tight control and scrutiny. The growing trend of commercialization is the main reason for strict regulation.

As the above discussion shows, in its early stage of development, the main mission of Indian microfinance is fighting poverty through outreach. In this regard, although there has been an imbalance across the regions in India, MFIs have been demonstrating high growth of outreach in the sector.

Moreover, like the main notion of microfinance, it is clear that Indian MFIs have double bottom line objectives, MFIs' social outreach, and financial sustainability (Morduch, 1999). Although some MFIs have been striving to achieve a balance between social and financial performance, competition makes it very challenging and sometimes lead to mission drift (Ngo, 2015).

However, now the rapid growth of commercialization in the Indian microfinance sector and competition pushes MFIs to change their social mission of providing access to finance for the unbanked segment of the population to profit-seeking institutions (Guha, 2013). In a competitive microfinance sector, achieving the double bottom line objectives is very challenging (Cull et al., 2011). Consequently, increasing competition creates frustration of poor financial performance that spurring MFIs to compromise their social mission. It has been witnessed that commercialized Indian MFIs provide larger loans, then non-commercialized MFIs (Taylor, 2001 and Wichterich, 2012) which shows that they might shift from their social mission.

Thus, whether market competition causes a shift in MFIs' mission needs to be investigated. In a competitive market, do MFIs shift from their social mission towards financial objectives? is needs to be answered. Consequently, the objective of this paper is to examine whether competition has a moderating effect on the relationship between MFIs' social mission and financial performance.

\section{Literature review}

In this section, a review of the literature on MFIs' performance and competition are provided. First, both theoretical and empirical evidence on the relationship between social and financial performance are discussed. Second, the effect of competition on MFIs' performance is reviewed. Finally, theories and literature that show the moderation effects of competition are discussed.

\section{Social and financial performance: theoretical review}

In the 1970s System theory was broken up the closedlope strategies of institutions. According to Ackoff (1970) system theory advocates that all partners within the network are incorporated in organizational decisionmaking and problem-solving. From a System theory point of view, the optimal strategy is the one that able to combine partners' interests in such that the firm's strategy is optimal for the network. Based on this theory, given the strategy of the partners, to formulate an optimal business approach, the organization is considering the mutual benefits of all partners in the network of the organization. Concerning system theory, stakeholder theory has brought to incorporate social issues into the business model of firms.

Stakeholder theory states that socially responsible institutions have better financial performance (Freeman, 
2010). Stakeholder theory helps to understand how incorporating the interests of stakeholder (customers) to influence the financial performance of the MFIs. It means it lays a foundation for the possible relationship between social and financial performance. This is because the domain of stakeholder theory thought out that satisfying the interest of customers has a positive direct contribution towards MFIs' profitability. Contextually, MFIs are expected to fulfill their social objective by offering financial services that meet the interest of poor or low-income people. This theory asserts that stakeholders should involve in the decision-making process of the organization and institutions have to consider the meeting of their need as an unavoidable cost of doing business (Freeman, 2010). In the stakeholder theory perspective, sustainability is based on the organization's understanding of the external environment and responds to those affected by its strategies. Stakeholder theory serves as a framework to examine the relationship between social and financial performance (Ruf et al., 2001) and has also supported by several empirical pieces of evidence. In line with stakeholder theory, studies found a positive relationship between social and financial performance.

Ruf et al. (2001) investigate the relationship between corporate social and financial performances from a stakeholder theory perspective. The result of their analysis suggests that improvement in social performance has both immediate and continuing impact on financial performance. This implies that meeting stakeholders' interests (achieving the social mission) provide a competitive advantage to retain market share and enhance profitability in the long run. Ribstein (2005) supports this view by arguing that incorporating corporate social responsibility builds strong stakeholder loyalty which in turn enhances financial performance. Moreover, achieving a social mission reduce unsystematic risks (Orlitzky \& Benjamin, 2001) and determine competitive advantage (Turban and Greening, 1996). Similarly, others have also found constant results in support of stakeholder theory (e.g. Cornell \& Shapiro, 1987; Preston \& O'bannon, 1997; Simpson \& Kohers, 2002). The evidence seems to support the view that developing favorable social performance (positive public image, good reputation, stakeholder satisfaction, etc.) results in promising financial performance.

\section{Social and financial performance's relationship: empirical review}

Starting from the early development stage of microfinance, there is an ongoing debate between two groups which is referred to as the "Welfarists" and "institutionalists" (Hudon, 2011). Based on the Welfarists' doctrine, microfinance is a bank that provides financial services to the poor, and designed as a development tool to fight against poverty (Woller, 2002). Whereas, institutionalists argue that to provide permanent financial services without subsidy, MFIs have to focus on self-sustainability (Robinson, 2001). Since then, the Microfinance industry is growing and getting diversified in the forms of product and services, ownership status, lending methodology, size, and goals. Of these diverse characteristics, MFIs have the double bottom line objective of social outreach and financial sustainability (Morduch, 1999). The nature of a relationship between MFIs' social mission and sustainability and whether they can pursue their social mission and become sustainable at the same time is part of the debates in microfinance literature for decades.

In microfinance literature, studies have been conducted to find out the nature of the relationship between social and financial performance and remain debatable. One group of scholars argues that there is a trade-off relationship between social and financial performance (e.g. Conning, 1999; Cull et al., 2008; D'Espallier, Goedecke, Hudon, \& Mersland, 2017; Hermes et al., 2011; Navajas, Schreiner, Meyer, Gonzalez-Vega, \& Rodriguez-Meza, 2000; Schreiner, 2002). On the other strand, scholars find that a positive complementary relationship exists between self-sustainability and outreach (e.g. Adhikary \& Papachristou, 2014; Montgomery \& Weiss, 2011; Quayes, 2012). Moreover, some findings show no or neutral relationship (e.g. Bassem, 2015; Lebovics, Hermes, \& Hudon, 2016). In the following section, evidence that supports both positive and trade-off relationships are discussed. First, empirical evidence that supports positive association will present, and then trade-off follows.

\section{Complementary (positive) relationship}

More recently, Adhikary and Papachristou (2014) find that MFIs' sustainability and outreach are positively correlated and have a complementary relationship. They argue that both depth and breadth of outreach are positively related to profitability (Return on Asset) and efficiency (cost per borrower) of MFIs. Furthermore, according to them, as compared to the better-off clients, serving the poorest segment of the population has lower credit risk; the smaller the loan size (depth of outreach) the lowest credit risk.

Montgomery and Weiss (2011), Quayes (2012) also suggest that MFIs are undertaking and achieving both financial and social missions concurrently. Likewise, social performance helps to develop mutual trust and increase customer participation, which in turn reduces delinquency and operating costs (Lapenu, 2007).

\section{Trade-off (negative) relationship}

Cull et al. (2008) argue that higher profitability is associated with low depth of outreach. Implies that MFI strives for profitability abandons the poor segment of the 
population from its portfolio. Hence, the trade-off relationship exists between MFI efficiency (financial performance) and serving low-income people (outreach) (Gonzalez, 2010; Maitrot, 2019). Besides, small loan sizes and high transaction costs of serving the poorest are the immediate reasons for the MFIs' high-interest rate (Mersland \& Strøm, 2010; Morduch, 2000; Rosenberg, Gonzalez, \& Narain, 2009). But, charging a high loan rate on a poor's portfolio to cover high operating costs emanates from doing a transaction with them has taken as a trade-off between outreach and financial performance (Schreiner, 2002). So, these authors claim that high transaction costs associated with small loan size impend effort of maximizing depth outreach without sacrificing financial stability.

Consistent with the above findings, because of the lack of collateral and high risks associated with poor clients, an MFI targets poor individual incur high operational costs, and shows the trade-off between social and financial performance (Bédécarrats, Baur, \& Lapenu, 2012; Nawaz \& Iqbal, 2015). Altogether, Bédécarrats, Baur, and Lapenu (2012) conclude that MFIs attain social and financial performance in both trade-off and synergy. Additionally, Morduch (2000) also supports these views by arguing that a trade-off relationship exists between profitability and outreach.

Ngo (2015) also finds strong empirical evidence for a trade-off relationship between financial performance and outreach. He argues that there is a threshold level for a trade-off to happen in which beyond this threshold level MFI maximizes their financial performance at the expense of the social mission. The above empirical evidence is also supported by other findings. For instance, Hermes et al. (2011) reveal a trade-off relationship between efficiency and outreach, were undertaking a social mission threatens MFI's cost efficiency.

Nevertheless, some evidences exposed neither a tradeoff nor a complementary relationship. Recently, Lebovics et al. (2016) find that Vietnamese's MFIs are both social and financially efficient, but neither trade-off nor synergy association exists between social outreach and financial sustainability. They assert that cost efficiency is indirectly correlated with the depth of outreach which implies targeting low-income people threatens efficiency. Other findings also support the above evidence. For instance, Bassem (2015) find a neutral relationship. Thus, based on the above empirical evidences, it can be thought out that, in microfinance, the trade-off between social and financial performances have demonstrated. So, a trade-off relationship is also expected.

Although the theoretical discussion consistently supports a positive relationship, the empirical findings in section 4.2.1 and 4.2.2 on the relationship between social and financial performance are mixed. Consequently, this paper proposed in both negative and positive hypotheses that hypothesize as:

\section{Hypothesis 1: social performance has a positive/ negative significant effect on financial performance}

\section{Competition \\ Competition measures}

Banking works of literature have been forwarded to different measures of Competition. Those measures are broadly classified into two paradigms, Structural Conduct Performance (SCP) and the New Empirical Industrial Organization (NEIO) paradigms. SCP paradigm measures competition based on market structure and assumes that the competition is lower in a concentrated market, but the profit is higher. Herfindahl-Hirschman Index (HHI) is one of the SCP technique (Van Leuvensteijn, Bikker, van Rixtel, \& Sørensen, 2011).

HHI value ranges from 0 to 1 . The value closer to 0 indicates high competition, whereas 1 indicates a monopoly structure. However, HHI is criticized by the fact that it doesn't take into account competitive behavior and bank's ownership, and its assumption also lacks theoretical support (Coccorese, 2009; Lau, 1982).

A New Empirical Industrial Organization (NEIO) approach is a nonstructural measure whereby competition is measured through estimating parameters that reflect the firm's competitive behavior. Panzar and Rosse statistics and the Lerner index are categorized under this approach. These indexes estimate firms' market competitive power by considering a bank or firm as an independent decisionmaking entity. $\mathrm{H}$-statistics estimates competition parameters based on the relationship between the price of inputs and equilibrium revenue. It ranges from 0 to 1,1 represents a perfect competition, market, and $\mathrm{H}=0$ represents monopoly competition (Panzar \& Rosse, 1987).

Learner Index is another most widely used measure of competition. In Learner Index, the firm's market power is estimated using its price $(\mathrm{P})$ and marginal cost $(\mathrm{MC})$, (P-MC) /MC. When the value of the Lerner index closes to zero, it shows the presence of intense competition, whereas when $\mathrm{PMC}>0$, competition is lower. Amir (2003) asserts that the learner index lacks a theoretical foundation and not a robust indicator.

Recently, Boone (2008) introduced a new measure of competition, Boone Indicator. Boone indicator works on the assumption that in a competitive market efficient firm always performs better than the inefficient one. The Boone indicator estimates competition between firms by considering the association of profit and marginal cost. Thus, according to Boone Indicator, in a competitive market inefficient firms lost their profit and market share. 
The new approach to measure competition has the advantage of handling MFIs' efficiency and market share relationship and allows them to easily measuring competition on the specific product-market (van Leuvensteijn et al., 2011). The details of the Boone Indicator presented in part 5 .

\section{Competition and MFIs' performance}

Vogelgesang (2003) finds twofold of effects between competition and MFIs; positive and negative. On one hand, high competition improves repayment behavior and induces clients to pay on time. On the other hand, competition increases the supply of loan which in turn creates a loan burden and then leads to defeat. Schicks and Rosenberg (2011) share Vogelgesang's second thought by arguing that competition creates overindebtedness which increase delinquency rate and impend the sustainability of MFIs.

McIntosh and Wydick (2005) analyze the impact of competition on clients' behavior and the results show that raising competition worsens delinquency rates. However, they also find that increased competition doesn't change the dropout rates and loan amount. According to them, the entrance of new competing lender leads to multiple loan taking which in turn worsen repayment performance and reduced saving level of borrowers. In a later study, McIntosh, Janvry, and Sadoulet (2005) examined the effect of competition on the performance of MFIs, which suggests that competition creates over-indebtedness and negative externalities. They find that competition increases asymmetric information between competing MFIs which negative influences both impatient and patient borrowers. Likewise, competition increases the supply of loans in the microfinance market and erodes the power of social capital to serve as collateral (Villas-Boas \& Schmidt-Mohr, 1999).

Assefa et al. (2013) suggest that competition has a negative relationship with outreach, which leads to conservative lending activities. On the other hand, they argue that competition has a positive significant effect on loan repayment which means leads to lower repayment rate, in turn, brings to more loans at risk and writes off. But, they conclude that competition negatively correlates with MFIs' financial performance. Olsen (2010) also confirms the negative relationship between competition and outreach.

As indicated above, competition leads to multiple loans taking which exacerbate the default rate and other indebtedness. However, Guha and Chowdhury (2014) argue that borrowing from multiple sources threatens the real impacts of MFIs in their society. They claim that in double-dipping situations MFIs are targeting poor people, not crowding out. Competition lowers interest rates, improves the quality of service, and enhances innovation in microfinance (Porteous, 2006). It can be contended that competition in microfinance has both positive and negative effects on MFIs' social and financial performances. Motta (2004) and Navajas, Conning, and Gonzalez-Vega (2003) also suggest that competition reduces operating costs and the price of a loan, and foster innovation among MFIs.

\section{Moderating effect of competition Theoretical background}

There are two theories of competition, competitionstability, and competition-fragility. The competitionstability theory is a competition theory that sees competition as a market stability force (Beck, 2008). Whereas, competition-fragility is a theory favors market concentration by assuming competition as a negative force towards the firm's performance (Carletti \& Hartmann, 2002).

From the competition-fragility theory point of view, lack of competition in the market develops rent-seeking behaviors among firms (Boyd \& De Nicolo, 2005). In such a market, MFIs are price setter rather than price takers. It creates a favorable environment for MFIs to increase prices up to the level that allows them to generate a large sum of profit (Bateman, 2010; Helms, 2004; Rosenberg et al., 2009). Due to this, borrowers bear all the risks to borrow money at a high loan price. Clients became a victim of the rent-seeking behavior of MFIs. It puts them in a higher loan burden and increases the probability of borrower strategic default. On such occasions, credit could appear as an obstacle rather than absorbing the risks of vulnerable poor borrowers.

On top of that, although charging higher interest rate increase MFIs' profit, it doesn't target the reality of poor borrowers. It means it is not in line with the very objective of MFI, poverty minimization. From these discussions, it seems that competition-fragility or concentration-stability theory supports that market concentration increases firms' profit but has a negative contribution to their social performance. In the absence of competition, there is a tradeoff between social and financial performances. Therefore, competition negatively moderates the relationship between social and financial performance.

On the contrary, the competition-stability theory views firms as price takers. The market is offering an affordable price to customers. Charging a reasonable price prevent the strategic defeat of the MFIs, thus keep their sustainability. As indicated above in the case of collusion, charging hefty interest rate lowers borrowers' repayment rate that in turn leads to bankruptcy. According to the competition-stability theory, the competition allows clients to have strong barraging power on the price of a loan and to get a required loan amount at an affordable price. These enhance the repayment performance of borrowers and so, the bank could have 
sustainable financial performance. Moreover, competition fosters innovation to offer products or services that tailored to the demand of the clients. Accordingly, the financial market offers a reasonable price for each segment of the population and then outreach could be maximized. Hence, competition positively moderates the relationship between social and financial performance.

\section{Empirical background}

In a competitive environment, being a socially responsible institution has a financial cost, which hurts the financial performance (Barnett \& Salomon, 2012; Fombrun et al., 2000; Friedman, 1970). Organizations participating in social development activities faced lower stock value as compared to the average and experience lower financial performance relative to competitors in the industry (Vance, 2011). If MFIs involved in the social mission, competition may threaten their financial performance. This is due to the additional costs of undertaking social activities.

In the less competitive market, MFIs serve not only lowincome people but also unbanked wealthier clients (Vanroose \& D'Espallier, 2013). Serving the better of clients represents a larger loan size and also profitable (Bateman, 2010). Indeed, providing larger loan size doesn't mean that the MFIs are not in line with their social objectives of serving a marginalized segment of the population, rather they are meeting their defined purpose trough crosssubsidization (Armendáriz \& Szafarz, 2009). Additionally, Vanroose and D'Espallier (2013) argue that MFIs reach a large number of people in a place where there is a less competitive market and also demonstrate good financial performance and sustainability.

On the other hand, in countries where there is high competition in the microfinance or banking sector, MFIs forced to go to the lower segment of the population (Cull et al., 2011; Vanroose \& D'Espallier, 2013). These MFIs have a deep depth of outreach through offering smaller loan sizes, but the Lower breadth of outreach. Besides, in a competitive market, MFIs obliged to decrease the interest rate to survive and compete in the market, which exacerbates the situation by unable to cover their operational costs. Though these MFIs are keeping their social mission of serving poor people by providing smaller loan sizes, their financial performance and sustainability are in danger because of significant transaction costs emanated from offering smaller loan sizes (Khanam, Parvin, Mohiuddin, Hoque, \& Su, 2018; Mersland \& Strøm, 2009). It can be thought out that when competition introduced in the market, social and financial performances' link has affected.

When competition increased, to attract both social and financially oriented stakeholders and investors, firms have to focus on increasing financial performance and at the same time investing in community development projects (Beisland, D’Espallier, \& Mersland, 2019; Kanwal, Khanam, Nasreen, \& Hameed, 2013).

Arguably, the analysis of theoretical and empirical evidence suggests that competition influences the relationship between MFIs' financial and social performances either positively or negatively. It implies that the strength and form of the relationship between social and financial performance may depend on the value or level of competition. In these senses, it can be hypothesized that;

\section{Hypothesis 2: competition has a positive or nega- tive moderating effect on the relationship be- tween social and financial performance (Fig. 1).}

\section{Methodology and data}

This section provides a discussion on competition measures, model specifications, and estimation methods. Additionally, the source and detail descriptions of the data are also briefly presented.

\section{Competition measures: Boone indictor}

As indicated in chapter two, this paper uses the new measure of competition which is Boone Indicator. Boone indicator is calculated by using the following profit function that measures competition in the market (Boone, 2008).

$$
\ln \pi_{\mathrm{it}}=\alpha+\sum_{\mathrm{t}=1}^{\mathrm{T}} \beta \operatorname{In}\left(\mathrm{MC}_{\mathrm{it}}\right)+\varepsilon_{\mathrm{it}}
$$

Where $\pi_{i t}$ stands the profit of MFI $i$ at year $\mathrm{t}$ which is proxied by Return on Asset (ROA), $\mathrm{MC}_{\mathrm{it}}$ represents the marginal cost of MFI $i$ at year $t, \beta$ is Boone indicator and $\mathcal{E}_{\text {it }}$ is the error term. Since the Boone indicator is based on the negative relationship between profit and cost, a negative coefficient value of $\beta(\beta<0)$ is expected. A higher negative value of $\beta$ indicates the presence of strong competition in the microfinance market, whereas a positive value of $\beta$ shows the existence of collusion (Van Leuvensteijn et al., 2011).

Equation 1 is used to measure the aggregate competition at the microfinance level. So, to capture the development of competition over the year, time dummies ( $d_{t}$ for each year) are added in the above equation which gives Eq. 2 below.

$$
\ln \pi_{\mathrm{it}}=\alpha+\sum_{\mathrm{t}=1}^{\mathrm{T}} \beta_{t} d_{t} \operatorname{In}\left(\mathrm{MC}_{\mathrm{it}}\right)+\sum_{\mathrm{t}=1}^{\mathrm{T}-1} \alpha_{t} d_{t}+\varepsilon_{\mathrm{it}}
$$

Additionally, obtaining the value of the Boone coefficient in Eq. 2 requires MC of MFI $i$ at time t. but $M C$ is not measured directly, following Van Leuvensteijn et al. (2011), a translog of cost function uses to estimates MC of MFI $i$ at year $t$. Therefore, the cost function in Eq. 3 


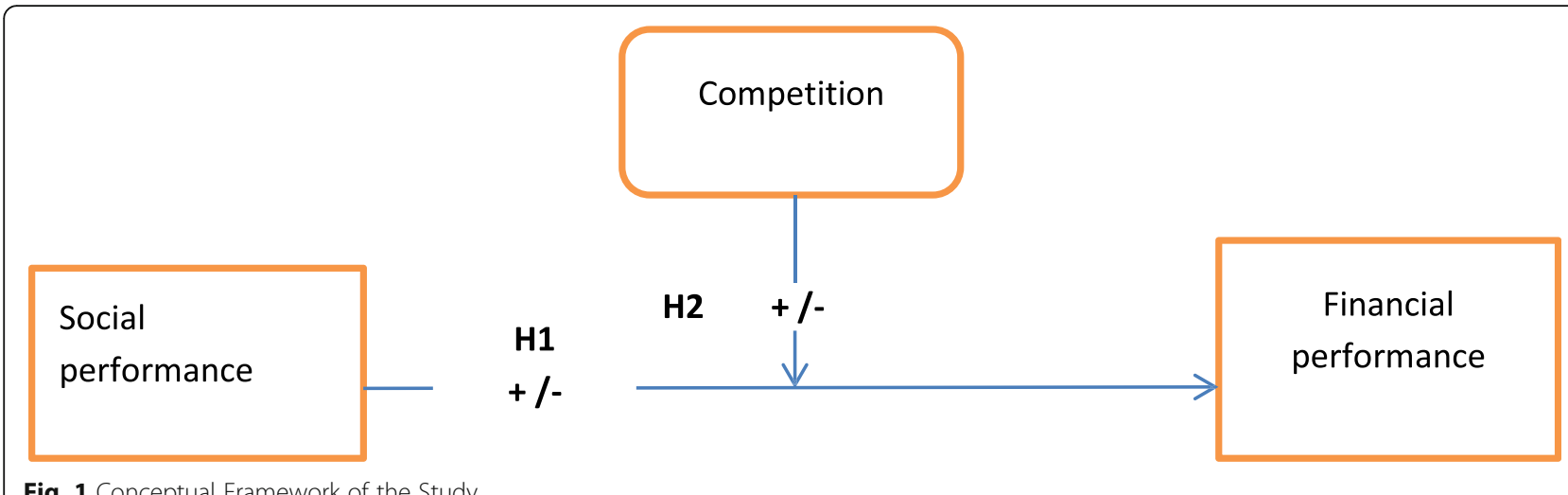

is applied to estimate parameters which are used to obtain $\mathrm{MC}_{\mathrm{it}}$.

$$
\begin{aligned}
\operatorname{InTC}_{\mathrm{it}}= & \alpha_{0}+\delta_{0} \operatorname{Inq}_{\mathrm{it}}+\frac{\delta 1}{2}\left(\operatorname{Inq}_{\mathrm{it}}\right)^{2} \\
& +\sum_{\mathrm{j}=1}^{3} \alpha_{\mathrm{j}} \operatorname{InW}_{\mathrm{jit}}+\sum_{j=1}^{2} \frac{1}{2} \alpha_{j}\left(i n w_{j i t}\right)^{2} \\
& +\operatorname{Inq}_{\mathrm{i}} \sum_{\mathrm{j}=1}^{3} \delta_{\mathrm{j}+1} \operatorname{InW}_{\mathrm{jit}} \\
& +\frac{1}{2} \sum_{\mathrm{j}, \mathrm{k}=1}^{3} \alpha_{\mathrm{jk}} \operatorname{InW}_{\mathrm{jit}} \operatorname{InW}_{\mathrm{kit}}+\sum_{t=1}^{T-1} \alpha_{t} d_{t} \\
& +\mathcal{E}_{\mathrm{it}}
\end{aligned}
$$

Where $\mathrm{TC}_{\mathrm{it}}$ stands for the total cost, (the sum of financial costs, labor costs, and administration costs) of MFI i at year $\mathrm{t}, \mathrm{q}_{\mathrm{it}}$ is an output of MFI $\mathrm{i}$ at year $\mathrm{t}$ which is proxied by gross loan portfolio, ${ }^{2} \mathrm{~W}_{\text {it }}$ represents the three input costs ${ }^{3}$ (cost of labor, cost of capital, and cost of fund) of MFI i at time $t$. The ratio of personnel expense to total assets, the ratio of financial expenses to total assets, and the ratio of administrative expenses to total assets are used as a proxy to measure the cost of labor, cost of fund, and cost of capital respectively.

In the above translog cost function, the input prices are linearly homogeneous (Delis, Iosifidi, \& Tsionas, 2014). Linear homogeneity assumes that total cost is the result of the three input prices. Thus, following linear homogeneity restrictions imposed on the translog cost function.

$$
\begin{gathered}
\sum_{j-1}^{3} \alpha_{j}=1 \ldots \ldots \ldots \ldots . .1 \sum_{j=1}^{3} \delta_{j+1}=0 \ldots \ldots \ldots \ldots \ldots . .2 \\
\sum_{j=1}^{3} \sum_{k=1}^{3} \alpha_{j k} \ldots \ldots \ldots \ldots \ldots \ldots \ldots \ldots \ldots . . . . \ldots \ldots \ldots \ldots
\end{gathered}
$$

$\mathrm{MC}$ as a first derivative of the cost function, Eq. 3.

\footnotetext{
${ }^{2}$ This has already applied in microfinance as output measures (see for example, Assefa et al., 2013; Hermes et al. (2011)

${ }^{3}$ All three ratios have already applied in microfinance (see Kar, 2016).
}

$$
\mathrm{MC}_{\mathrm{it}}=\frac{\delta \mathrm{TC}_{\mathrm{it}}}{\delta \mathrm{q}_{\mathrm{it}}}=\frac{\mathrm{TC}_{\mathrm{it}}}{\mathrm{q}_{\mathrm{it}}}\left(\delta_{0}+\delta_{1} \ln q_{i t}+\sum_{\mathrm{j}=1}^{3} \delta_{\mathrm{j}+1} \ln \mathrm{W}_{\mathrm{ijt}}+\sum_{t=1}^{T-1} \alpha_{t} d_{t}\right)
$$

Where $\mathrm{MC}_{\mathrm{it}}$ is the marginal cost of MFI $i$ at time $t, \mathrm{TC}_{\mathrm{it}}$ is the total cost of MFI $i$ at time $t, q_{i t}$ is output (gross loan portfolio) and $\mathrm{W}_{i t}$ represents inputs price (cost of labor, cost of capital and cost of fund) of MFI $i$ at time t. the value of $\mathrm{MC}_{\mathrm{it}}$ obtains by substituting the parameters estimated using the translog cost function in Eq. 2.

\section{MFIs' performance measures}

Social performance and competition are independent variables of the study. According to Rosenberg et al. (2009), social performance is the social impact of MFIs in providing financial service to low-income people. The social performance was measured by using depth of outreach which is gaged through depth (average outstanding loan to GNI per capita) and breadth of outreach (active number of borrowers).

Financial performance is the ability to cover all operating costs from operating income (Rosenberg et al., 2009), measured by Return on Asset (ROA), Return on Equity (ROE) and Operational Self-Sufficiency (OSS). Control variables are MFI size, MFI age, and donation. The linear regression model for financial and social performance variables are indicated below in Eq. 4, and the moderating effect of competition represented by Eq. 5 (Table 1).

The depth and breadth of outreaches are the two most known measures of the social performance of MFIs. As one of the social performance indicators, depth of outreach refers to the type and poverty level of clients served by MFIs. The breadth of outreach refers to the number of active clients served by MFIs which indicates their scale of operations (Rosenberg et al., 2009). The most common proxies used to measure the depth and breadth of outreaches are average outstanding loan (gross loan portfolio to the active number of clients) as a percentage of per capita Gross National Income (GNI) 
Table 1 Definition of variables in the empirical analysis

\begin{tabular}{|c|c|c|}
\hline Variables & Definitions and measurements & Authors that use the variables \\
\hline \multicolumn{3}{|c|}{ Social performance measures } \\
\hline $\begin{array}{l}\text { Depth of } \\
\text { Outreach }\end{array}$ & $\begin{array}{l}\text { Average outstanding loan (Gross loan portfolio to Active number of } \\
\text { clients) as a percentage of per capita Gross National Income (GNI); } \\
\text { measures how deeply MFIs reach poor clients }\end{array}$ & Rosenberg et al., 2009 \\
\hline $\begin{array}{l}\text { Breadth of } \\
\text { Outreach }\end{array}$ & $\begin{array}{l}\text { The logarithm of the number of active clients served: measures how } \\
\text { MFIs expanding financial services to its clients }\end{array}$ & Rosenberg et al., 2009 \\
\hline \multicolumn{3}{|c|}{ Financial performance measures } \\
\hline $\begin{array}{l}\text { Return on } \\
\text { Asset (ROA) }\end{array}$ & $\begin{array}{l}\text { Computes by dividing net operating income by average assets; } \\
\text { measures MFIs' ability to utilize resources profitably }\end{array}$ & Rosenberg et al., 2009 \\
\hline $\begin{array}{l}\text { Operational } \\
\text { Self Sufficiency } \\
\text { (OSS) }\end{array}$ & $\begin{array}{l}\text { Obtains by dividing operating income by total expenses; measures the } \\
\text { MFls' ability to cover all expenses by income generated from } \\
\text { operational activities. }\end{array}$ & Rosenberg et al., 2009 \\
\hline \multicolumn{3}{|c|}{ Competition measures } \\
\hline $\begin{array}{l}\text { Boone } \\
\text { indicator }\end{array}$ & $\begin{array}{l}\text { A proxy for competition; the value of } \beta\left(\beta 2 X_{j t}\right) \text { in Eq. 5; large negative } \beta \\
\text { indicates a higher competition level }\end{array}$ & Boone (2008) \\
\hline Output & Measured by gross loan portfolio & $\begin{array}{l}\text { Assefa et al., 2013; Hermes et al. (2011); Van Leuvensteijn } \\
\text { et al. (2011) }\end{array}$ \\
\hline cost of labor & The ratio of personnel expenses to total assets & Kar, 2016; Van Leuvensteijn et al. (2011) \\
\hline cost of fund & The ratio of financial expenses to total liabilities & Kar, 2016; Van Leuvensteijn et al. (2011) \\
\hline $\begin{array}{l}\text { cost of } \\
\text { physical capital }\end{array}$ & The ratio of administrative expenses to total assets & Kar, 2016; Van Leuvensteijn et al. (2011) \\
\hline \multicolumn{3}{|l|}{ Control variables } \\
\hline MFI_age & Service year & Assefa et al., 2013; Cull et al., 2009; Hermes et al. 2011 \\
\hline MFI_size & Log of total assets & Assefa et al., 2013; Cull et al., 2009; Hermes et al. 2011 \\
\hline MFI_owndum & $\begin{array}{l}\text { Dummy variable to capture the effect of ownership status ( } 1 \text { for NBFI, } 0 \\
\text { otherwise) }\end{array}$ & Mersland and Strøm (2010) \\
\hline Risk level & Total equity to total assets ratio & Cull et al., 2009 \\
\hline
\end{tabular}

and the logarithm of the number of active clients served respectvlly (Assefa et al., 2013; Cull et al., 2009; Hermes et al. 2011; Rosenberg et al., 2009).

Return on Asset (ROA), and Operational Self Sufficiency (OSS) are used to measure MFIs' financial performance. ROA measures the MFIs' ability to use its resources profitably. ROA calculates by dividing net operating income by average assets. OSS reflects the MFIs' ability to cover all expenses through income generated from operational activities and calculates by dividing operating income by total expense.

The Boone indicator is used to measure competition based on the assumption that in a competitive market efficient firm always performs better than the inefficient one. It estimates competition between firms by considering the association of profit and marginal cost. Thus, according to Boone Indicator, in a competitive market inefficient firms lost their profit and market share (Boone, 2008). Since the Boone indicator is based on the negative relationship between profit and cost, a negative coefficient value of $\beta(\beta<0)$ is expected. A higher negative value of $\beta$ indicates the presence of strong competition in the microfinance market, whereas a positive value of $\beta$ shows the existence of collusion (Van Leuvensteijn et al., 2011).

However, obtaining the value of the Boone coefficient as specified above requires the marginal cost of MFIs and on top of that marginal cost is not measured directly. One output and three inputs are used to estimate parameters that are used to obtain the marginal cost of MFIs (Hermes et al. 2011). MFIs' output proxied by gross loan portfolio. Three input costs (the cost of labor, cost of capital, and cost of fund) are used as inputs variables. The ratio of personnel expense to total assets, the ratio of financial expenses to total assets, and the ratio of administrative expenses to total assets are used as a proxy to measure the cost of labor, cost of fund, and cost of capital respectively.

Moreover, institutions level variables are added to control for the firm-specific situation. MFIs' age (years since establishment), size (measured as the log of the total asset), ownership status (the possession of MFIs as None Bank Financial Institution, NBFI), and risk level (equity to total asset) are considered as control variables. 


\section{Model specification}

$$
\begin{aligned}
\mathrm{FP}_{\mathrm{it}}= & \alpha+\beta_{1} \mathrm{SP}_{\mathrm{it}}+\beta_{4}(\text { MFI_age })_{i t} \\
& +\beta_{5}(\text { MFI_size })_{i t}++\beta_{7}(\text { MFI_owndum })_{\mathrm{it}} \\
& +\beta_{8}(\text { MFI_risk })_{i t}+\mathcal{E}_{\mathrm{it}} \\
\mathrm{FP}_{\mathrm{it}}= & \alpha+\beta_{1} \mathrm{SP}_{\mathrm{it}}+\beta_{2} \mathrm{~B}_{\mathrm{jt}}+\beta_{3} \mathrm{M}_{\mathrm{it}} \\
& +\beta_{4}(\text { MFI_age })_{i t}+\beta_{5}\left(M F I \_ \text {size }\right)_{i t} \\
& +\beta_{6}(\text { MFI_owndum })_{\mathrm{it}}+\beta_{7}(\text { MFI_risk })_{i t} \\
& +\mathcal{E}_{\mathrm{it}}
\end{aligned}
$$

$\mathrm{FP}_{\mathrm{it}}$ is the financial performance of MFI $i$ at time $\mathrm{t}, \mathrm{SP}_{\mathrm{it}}$ is the social performance of MFI $i$ at time $t, B_{j t}$ is a degree of competition as measured by Boone indicator and $\mathrm{M}\left(\mathrm{SP}_{\mathrm{it}} * \mathrm{~B}_{\mathrm{jt}}\right)$ is moderating variable obtains by multiplying mean-centered value of $\mathrm{SP}_{\mathrm{it}}$ and $\mathrm{B}_{\mathrm{jt}}$. In both models, MFI_age, MFI_size ownership status, and MFI risk are control variables.

\section{Estimation methods}

To test the relationship between social and financial performance, Fixed Effect regression is employed. The motivation to employ Fixed Effect Model is to control for time-invariant characteristics that may bias the endogenous and exogenous variables (Baltagi, 1995). Additionally, the Hausman Test has applied to verify whether the error term is correlated with the predictor variables, and the result shows that the $P$-Value is significant, the PValue of the Hausman test is $<0.05$. Thus, the null hypothesis that the error term is not correlated with predictors is not rejected. In such a case, the Fixed Effect Model is appropriate (Greene, 2008).

The translog cost function (Eq. 3) was estimated using a stochastic frontier -the time-variant inefficient model has employed. This approach has been widely used for efficiency analysis in banking literature and recently also in microfinance literature. ${ }^{4}$ The time-variant inefficient model states that time and entity-specific variables significantly influence the technical inefficiencies (Battese \& Coelli, 1992). Specifically, competition is subjected to technological change. Thus, the time-variant inefficient model is important to track the effect of a time trend.

The development of competition over time (Eq. 2) is estimated by using Two steps Generalized Method of Moments (GMM). The motivation for applying GMM is to control the endogeneity problems that emanate from the simultaneous estimation of cost and performance (Schaeck \& Čihák, 2008; Van Leuvensteijn et al., 2011). Regressing the profit variable (ROA) on the cost variable (MC) brings the endogeneity problem. It means that the change in profit also leads to a change in cost. The joint determination of these endogenous variables makes the error term to be correlated with exogenous.

\footnotetext{
${ }^{4}$ In microfinance see for example (Kar, 2016) and Hermes et al. (2011).
}

In the estimation of GMM, one lag of marginal cost is used as instrumental variables. The expected values of the Boone Indicator are negative $(\beta<0)$, whereby high competition in the microfinance market is observed. The positive value of $\beta(\beta>0)$ indicates the existence of collusion in the market. The higher negative value of $\beta$ represents the strong competition in the market. Sargan- Hansen test is also used to identify the validity of the instruments.

\section{Data descriptions and sources}

The sample consists of Indian MFIs. For this research, MFIs' Data and India's GNI per capital will be collected from the Microfinance Information Exchange (MIX), and World Bank development indicators respectively. MIX Market is the most widely used source of data for microfinance studies. The study is based on 10 years of penal data cover a period of 2005-2014.

Table 2 shows the general description of MFIs in the data set of this study. The analysis is based on unbalanced panel data where observation per MFI ranges from 1 year to 10 years. MFIs are included in the sample based on the availability and quality of their data. The data set uses in the study contains 183 MFIs, 84 NGOs, 83 NBMFIs, and 16 Rural Bank and Cooperative. Among 183 MFIs in the data set, 33 MFIs are young, less than 5 years operation, and 150 MFIs are mature more than 5 years operation.

Table 3 presents the summary statistics of both dependent and predictor variables used in the econometric analysis. In the statistics table, mean, standard deviation, minimum and maximum values of both dependent and explanatory variables are shown. In addition to the variables shown in Table 3, Control variables, age dummy, and MFI ownership status dummy thoroughly included in the analysis but aren't presented in the table.

Return on Asset and Operational Self-sufficiency (OSS) are financial performance variables. Log of Number of Active Borrower (lnNAB) and average loan portfolio to GNI (Depth) is social performance variables. The log of Total cost (TC) is used as a dependent variable in the translog cost function that applied to find marginal cost estimators.

Table 2 Description of MFls used in the empirical analysis

\begin{tabular}{ll}
\hline MFI legal Status & Numbers \\
\hline NGO & 84 \\
NBMFI & 83 \\
Rural Bank and Credit Union & 16 \\
Total & 183 \\
Age $^{a}$ & \\
$\quad$ Young & 33 \\
$\quad$ Mature & 150
\end{tabular}

${ }^{a}$ Age represents MFI's service years, but due to the absence of number years data that MFIs have been in services, MIX-Market labels MFI as NEW for a beginner (1 year service), YOUNG for less than 5 years' operation and MATURE for more than 5 years' services 
Table 3 Summary statistics of variables used in the analysis

\begin{tabular}{|c|c|c|c|c|c|}
\hline Variable & Obs & Mean & Std. Dev. & Min & Max \\
\hline \multicolumn{6}{|l|}{ Dependent variables } \\
\hline Return on Asset (ROA) & 828 & 0.000842 & 0.125458 & -2.3432 & 0.5627 \\
\hline Operational Self-Sufficency (OSS) & 920 & 1.108934 & 0.397338 & -0.6836 & 6.1197 \\
\hline \multicolumn{6}{|l|}{ Independent variables } \\
\hline Average Loan size (ALS) & 950 & 286.1426 & 3810.386 & 0.050209 & $117,488.5$ \\
\hline Gross Loan Prtofolio (GLP) in \$ (USD) & 989 & $3.68 \mathrm{E}+07$ & $1.16 \mathrm{E}+08$ & 60 & 1.53E+ 09 \\
\hline Total Cost (TC) in \$ (USD) & 826 & $8,524,235$ & $2.38 \mathrm{E}+07$ & 0.0595 & $2.24 \mathrm{E}+08$ \\
\hline Log of Total Cost (InTC) & 826 & 14.08078 & 2.137252 & -2.82178 & 19.22688 \\
\hline No Of Active Borrower (NAB) & 951 & $234,832.8$ & $682,991.9$ & 6 & $6,523,113$ \\
\hline $\log (N A B) \ln N A B$ & 951 & 10.4852 & 1.995558 & 1.791759 & 15.69086 \\
\hline Average Loan portfolio to GNI (Depth) & 950 & 0.289806 & 4.703837 & 0.000062 & 145.0475 \\
\hline Financial Expense to Liability (FEL) & 813 & 0.128139 & 0.659352 & 0.000301 & 18.8517 \\
\hline Administrative Expense to Asset (AEA) & 755 & 0.045536 & 0.04787 & 0.0009 & 0.6866 \\
\hline Personnel Expense to Asset (PEA) & 754 & 0.062621 & 0.04388 & 0.0006 & 0.4688 \\
\hline \multicolumn{6}{|l|}{ Control Variables } \\
\hline Log of Total Asset (MFI_size) & 971 & 15.49639 & 2.100206 & 4.779123 & 20.83353 \\
\hline Equity to Total Asset (Risk Level) & 966 & 0.242958 & 0.609972 & -1.09249 & 17.75329 \\
\hline
\end{tabular}

The three input prices, Financial Expense to Liability (FEL), Administrative Expense to Asset (AEA) and Personnel Expense to Asset (PEA), and output (GLP) are exogenous variables employed in the translog cost function. Similarly, the Log of Return on Asset (ROA) uses as a dependent variable in the Boone profit function to estimate the competition coefficient of the Indian microfinance market.

\section{Analysis of results}

This section presents the discussion of the estimation results of the study and the test results of the hypotheses in the conceptual framework. First, estimations on the association between social and financial performances are presented, and then competition and its moderation impacts are followed (Fig. 2).

\section{Social and financial performance}

Table 4 shows the regression results of the effect of social performance (SP) on financial performance (FP).

In model 1, operational self-sufficiency is regressed on social performance variables (depth and breadth of outreach) and the result shows P-Value is significant. This implies that depth and breadth of outreach have a statistically positive ${ }^{5}$ significant relationship with operational self-sufficiency. Similarly, in model2, ROA has a positive significant relationship with depth and breadth of outreach. Thus, when outreach increases, sustainability and profitability also increase. The results confirm the hypothesis that MFIs' social performance has a positive

${ }^{5} \beta$ coefficients of depth and breadth of outreach are positive. effect on their financial performance. Thus, this rejects the null hypothesis that there is no relationship between MFIs' social and financial performance. These lead to support hypothesis $1(\mathrm{H} 1)$ that MFIs' social performance has a positive significant effect on financial performance. The results of this hypothesis are also in line and consistent with the study of Adhikary and Papachristou (2014), Montgomery and Weiss (2011) and Quayes (2012). They found a similar result that social outreach and financial performance (profitability and sustainability) have a positive complementary relationship. It is also in line with stakeholder theory that meeting customers' interest is positively related to the financial performance of firms.

To check the form of relationship, one lag and one led variables are used from both depth and breadth variables. The result shows (see Appendix) OSS has both lead and lag form of relationship with the breadth of outreach. This lag result implies that the previous year's breadth of outreach has a positive influence on MFIs' operational self-sufficiency of this year. Increasing the number of active borrowers in the current year will have a positive contribution to the next year's sustainability of MFIs. Thus, participating in social development activities has a positive contribution to the MFIs' future financial performance. Similarly, Breadth of this year has also a significant relationship with the previous year's MFIs' sustainability. It means the accumulation of financial resource matter to the maximizing breadth of outreach.

But, the form of relationship between OSS and depth of outreach is neither lags nor led rather cotemporal. 


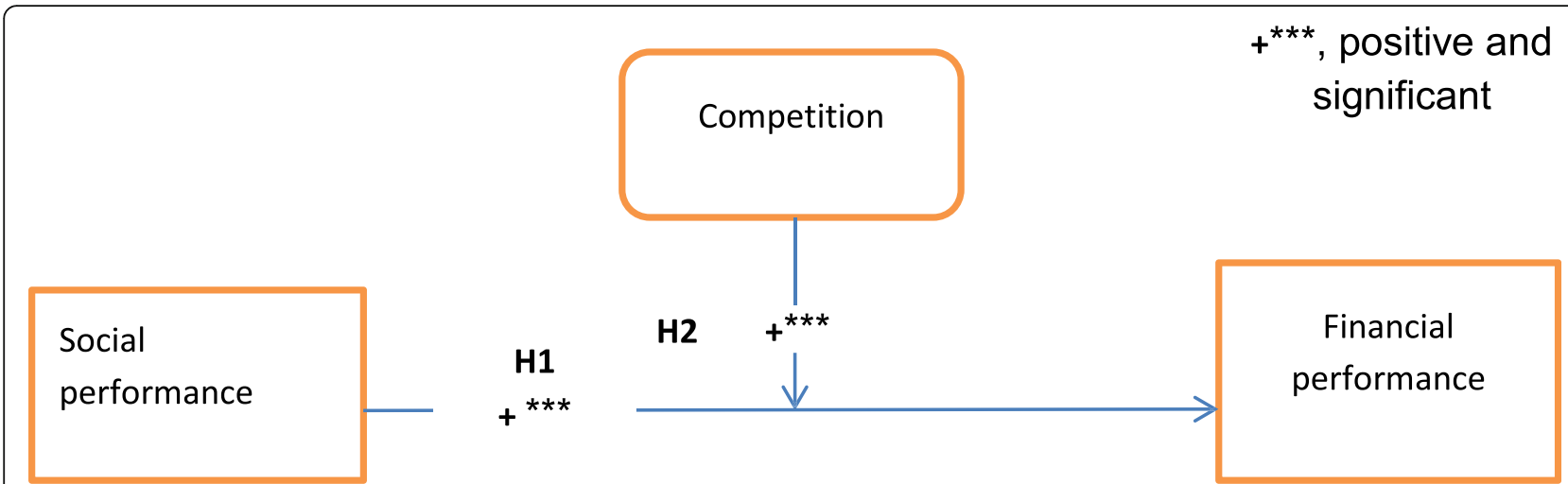

Fig. 2 Conceptual Framework of the Study with Empirical Results

The depth of outreach has a cotemporal relationship with OSS. On the other hand, the lag of breadth (log of the active number of borrowers) and depth of outreach are not significant with ROA.

\section{Estimation of marginal cost parameters: translog cost function}

Table 5 shows the estimation results of time-variant inefficient models, translog cost function. Most of the explanatory variables included in the model are significant with the total cost, hence partly depicts the robustness of the model. The time decay coefficient $(\eta)$ of the model is different from 0 exposes that time and random effects are significant.

Table 4 Regression results --effect of social performance on financial performance

\begin{tabular}{|c|c|c|}
\hline Variables $^{a}$ & $\begin{array}{l}\text { (1) } \\
\text { OSS }\end{array}$ & $\begin{array}{l}\text { (2) } \\
\text { ROA }\end{array}$ \\
\hline depth & $0.572^{* *}(0.227)$ & $0.754^{* * *}(0.0970)$ \\
\hline $\ln N A B$ & $0.161^{* * *}(0.0250)$ & $0.143^{* * *}(0.0120)$ \\
\hline MFI_size & $0.00560(0.0247)$ & $0.100^{* * *}(0.0113)$ \\
\hline $\mathrm{RL}$ & $0.289^{* * *}(0.0604)$ & $0.186^{* * *}(0.0275)$ \\
\hline age_dum & $0.00102(0.0258)$ & $0.0193^{*}(0.0106)$ \\
\hline Constant & $-0.742^{* * *}(0.190)$ & $-0.237^{* * *}(0.0880)$ \\
\hline Observations & 879 & 808 \\
\hline R-squared & 0.244 & 0.237 \\
\hline Prob $>$ F & 0.0000 & 0.0000 \\
\hline \multicolumn{3}{|l|}{ Hausman } \\
\hline Prob $>$ chi $2=$ & 0.0000 & \\
\hline \multicolumn{3}{|l|}{ Time-effect } \\
\hline Prob $>$ F & 0.0000 & \\
\hline
\end{tabular}

The effect of technological development that captured by year dummies ${ }^{6}$ is also significant. Additionally, as shown in the table, the sum of input prices' coefficient equals one proves that the linear homogeneity restriction has imposed on input prices is satisfied.

The focus of translog cost function analysis isn't to examine the cost efficiency of MFIs, rather to finds parameters to be used for marginal cost estimations. Thus, those parameters required for calculating the marginal cost of MFI $i$ at year $t$ are taken from the Table 5 above and used for generating marginal cost value of MFIs at each year by substituting in the marginal cost equation, Eq. 4.

\section{Estimation of competition over the years}

Table 6 shows the estimation of Eq. 2 using Two steps Generalized Method of Moments (GMM). In the estimation, the log of Return on Asset (ROA) is a dependent variable. Year dummies are added to capture the evolution of competition over the years.

The result of Table 6 is also shown graphically in Fig. 3 that represents the evolution of competition over the years, 2005-2014. As expected the values of the Boone coefficient are negative except for the year 2012. Thus, strong competition among Indian MFIs has been undertaken from the year 2005-2014. The positive Boone coefficient observed in the year 2012 is may be due to the presence of market collusion or MFIs were focusing on enhancing demand by increasing their cost expenditures and competition by quality (Dick, 2007).

The results suggest that in the period covered in this study, 2005-2012, the Indian microfinance market was very competitive. As represented in Fig. 3, the evaluation of competition from 2005 to 2014 is somehow dynamic. In the years 2005 to 2008, the microfinance market is

\footnotetext{
${ }^{6}$ Year dummies are included in the model but not reported and model test is enclosed in the Appendix.
} 
Table 5 MC parameters estimation with time-variant inefficient model

\begin{tabular}{|c|c|c|c|c|c|c|}
\hline $\operatorname{lnTC}$ & Coef. & Std. Err. & Z & $P>z$ & [95\% Conf. & Interval] \\
\hline Log of output (Iny) & 0.461735 & 0.106461 & 4.34 & 0.000 & 0.253077 & 0.670394 \\
\hline Cost of labor(Inw1) & 0.568387 & 0.15546 & 3.66 & 0.000 & 0.263691 & 0.873083 \\
\hline Cost ofphysical(Inw2) & 0.772551 & 0.173515 & 4.45 & 0.000 & 0.432469 & 1.112634 \\
\hline Cost of fund(Inw3) & -0.34094 & 0.116867 & -2.92 & 0.004 & -0.56999 & -0.11188 \\
\hline$(\operatorname{lny}) \wedge 2$ & 0.028881 & 0.006913 & 4.18 & 0.000 & 0.015332 & 0.04243 \\
\hline$(\ln w 1) \wedge 2$ & 0.076606 & 0.020712 & 3.7 & 0.000 & 0.03601 & 0.117201 \\
\hline$(\ln w 2) \wedge 2$ & 0.042823 & 0.021275 & 2.01 & 0.044 & 0.001126 & 0.084521 \\
\hline$(\ln w 3 w)^{\wedge} 2$ & 0.018547 & 0.012344 & 1.5 & 0.133 & -0.00565 & 0.042741 \\
\hline Inylnw1 & -0.01572 & 0.009599 & -1.64 & 0.102 & -0.03453 & 0.003094 \\
\hline Inylnw2 & -0.01727 & 0.009009 & -1.92 & 0.055 & -0.03493 & 0.00039 \\
\hline Inylnw3 & 0.032986 & 0.008623 & 3.83 & 0.000 & 0.016085 & 0.049888 \\
\hline $\ln w 1 \ln w 2$ & 0.009218 & 0.017187 & 0.54 & 0.592 & -0.02447 & 0.042905 \\
\hline Inw1lnw3 & -0.0818 & 0.029779 & -2.75 & 0.006 & -0.14016 & -0.02343 \\
\hline Inw2lnw3 & 0.072577 & 0.03417 & 2.12 & 0.034 & 0.005604 & 0.13955 \\
\hline _cons & 4.822352 & 0.885394 & 5.45 & 0.000 & 3.087012 & 6.557691 \\
\hline$\mu$ & 0.722708 & 0.272279 & 2.65 & 0.008 & 0.189051 & 1.256364 \\
\hline$H$ & -0.01641 & 0.018225 & -0.9 & 0.368 & -0.05213 & 0.019306 \\
\hline $\ln \ln \sigma^{2}$ & -2.28997 & 0.080187 & -28.56 & 0.000 & -2.44714 & -2.13281 \\
\hline $\ln \{\gamma /(1-\gamma)\}$ & -0.31352 & 0.208129 & -1.51 & 0.132 & -0.72145 & 0.094402 \\
\hline$\sigma^{2}$ & 0.101269 & 0.008121 & & & 0.086541 & 0.118504 \\
\hline Y & 0.422255 & 0.050774 & & & 0.327074 & 0.523583 \\
\hline$\sigma_{u}^{2}$ & 0.042762 & 0.008041 & & & 0.027002 & 0.058521 \\
\hline$\sigma_{v}^{2}$ & 0.058508 & 0.0035 & & & 0.051648 & 0.065368 \\
\hline Observations & 746 & 746 & 746 & 746 & 746 & 746 \\
\hline
\end{tabular}

Table 6 Estimation of competition: Boone indictor

\begin{tabular}{ll}
\hline Variables & $(1)$ \\
& InROA \\
\hline mc2005 & $-0.110(0.455)$ \\
mc2006 & $-0.473(0.385)$ \\
mc2007 & $-0.908(0.822)$ \\
mc2008 & $-2.265^{*}(1.257)$ \\
mc2009 & $-1.069^{*}(0.587)$ \\
mc2010 & $-1.178^{* * *}(0.437)$ \\
mc2011 & $-0.721(0.860)$ \\
mc2012 & $0.394(0.560)$ \\
mc2013 & $-0.700^{* *}(0.310)$ \\
mc2014 & $-0.446(0.329)$ \\
Constant & $-4.677^{* * *}(0.563)$ \\
Observations & 621 \\
Hansen test: over. & $: p=0.001$ \\
\hline
\end{tabular}

Standard errors in parentheses

${ }^{* * *} p<0.01,{ }^{* *} p<0.05,{ }^{*} p<0.1$ highly competitive whereby the competition increased at an increasing rate and then after, from 2009 to 2012, although it is competitive, it experiences a decreasing trend, but increases again after the year 2012.

\section{Moderating effects of competition}

Table 7 shows the estimation results of the competition's moderating effect on the relationship between social and financial performance. Operational Self-Sufficiency (OSS) is a dependent variable that regressed on DEPTH, BREADTH, competition (BI), moderation term, and other control variables. The interaction term ${ }^{7}$ is a moderating variable created by multiplying competition (BI) and DEPTH-Model 1, (M1), ${ }^{8}$ and competition (BI) and BREADTH -model 2, (M2). ${ }^{9}$

\footnotetext{
${ }^{7}$ The moderator variable is formed after mean centering of variables (B, DEPTH and BREADTH) to control multicollinearity problem that arises between the predictors and interaction term.

${ }^{8}$ To capture the moderation between depth of outreach and financial performance.

${ }^{9}$ To capture the moderation between breadth of outreach and financial performance.
} 


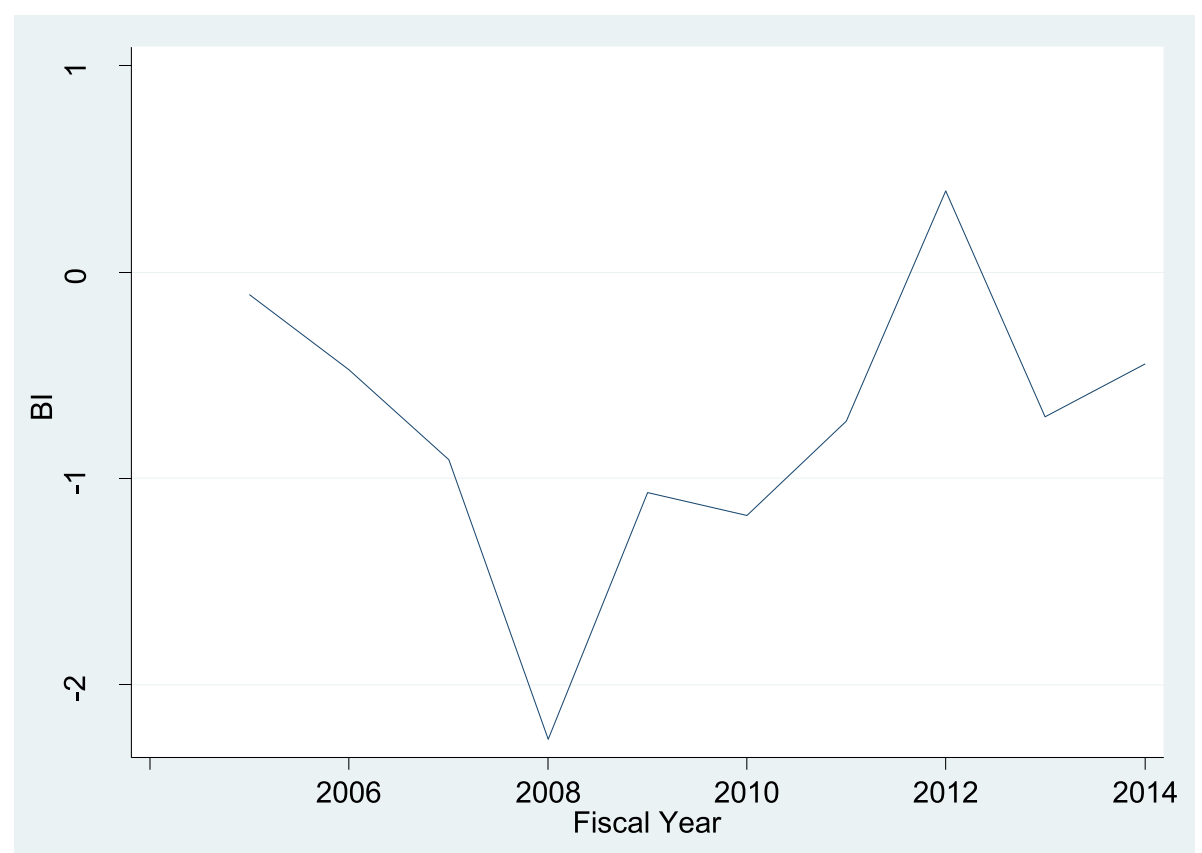

Fig. 3 Evolution of competition: Boone Indicator (BI)- (2005-2014)

The moderation test focuses on whether the causal relationship between social and financial performance changes due to competition. Model one represents the moderating effect of competition on the relationship between operational self-sufficiency and depth of outreach, M1. Model 2 estimates the moderating effect of competition on the relationship between operational selfsufficiency and breadth of outreach, M2.

In model 1 the result shows that the moderating variable, M1, is significant at $P$-value $<0.05$. Thus, moderation has occurred (Baron \& Kenny, 1986). The study hypothesized that competition has a positive or negative moderating effect on the relationship between social and

Table 7 Competition's moderating effect on OSS, and SP

\begin{tabular}{llll}
\hline Variables & $(1)$ & Variables & $\begin{array}{l}(2) \\
\end{array}$ \\
\hline OSS & & OSS \\
\hline BI & $0.0768^{*}(0.0408)$ & InNAB & $0.124^{* * *}(0.0164)$ \\
M1 & $-0.0501^{* *}(0.0242)$ & $\mathrm{BI}$ & $-0.0185(0.0199)$ \\
MFI_size & $0.216^{* *}(0.109)$ & $\mathrm{M} 2$ & $0.0184(0.0128)$ \\
MFI_Satudum & $-0.0185^{* *}(0.00745)$ & MFI_size & $-0.0809^{* * *}(0.0154)$ \\
RL & $0.0925(0.0643)$ & RL & $0.159^{* *}(0.0630)$ \\
age_dum & $0.0285(0.0308)$ & age_dum & $0.0214(0.0299)$ \\
Constant & $0.770^{* * *}(0.116)$ & Constant & $1.047^{* * *}(0.121)$ \\
Observations & 879 & Observations & 879 \\
R-squared & 0.28 & R-squared & 0.25 \\
\hline
\end{tabular}

Standard errors in parentheses

${ }^{* * *} p<0.01,{ }^{* *} p<0.05,{ }^{*} p<0.1$ financial performance, H2. The results evidence the hypothesis that competition has a positive moderating effect on the relationship between MFIs' social and financial performance. The results in Table 7 show the relationship between M1 (competition in model one) and OSS is significant at $P$-value $<0.05$. Hence, hypothesis $2(\mathrm{H} 2)$ is accepted. This leads to rejecting the null hypothesis that MFIs market competition doesn't moderate the relationship between MFIs' social and financial performance. Thus, the relationship between depths of outreach and operational self-sufficiency (OSS) is conditional upon competition. The positive $\beta$ coefficient implies that competition influences the relationship between the depth of outreach and operational selfsufficiency positively. It implies that in a competitive market, the more MFI deepen their depth of outreach, the higher contribution it has to their operational selfsufficiency. As compared with the regression result found in Table 4, the moderation isn't partial moderation rather complete. This is because of the strength and magnitude of the relationship between depth and OSS change by competition.

Additionally, In model 2 of Table 7, the moderating variable (M2) is not significant, so, moderation hasn't occurred. This Implies that Competition doesn't moderate the relationship between the breadth of outreach and operational self-sufficiency. Similarly, Table 8 shows that moderation hasn't occurred between ROA and any of the social performance variables. Consequently, no moderation occurred 
Table 8 Competition's moderating effect on the relationship between ROA, and social performance

\begin{tabular}{llll}
\hline Variables & $(1)$ & Variables & $\begin{array}{l}(1) \\
\text { ROA }\end{array}$ \\
\hline Depth & $0.00303(0.0135)$ & InNAB & $0.00971^{*}(0.00575)$ \\
BI & $-0.0142^{*}(0.00805)$ & $\mathrm{Bl}$ & $-0.0128^{*}(0.00709)$ \\
M1 & $0.00870(0.0361)$ & M2 & $0.000689(0.00481)$ \\
MFI_size & $0.00793^{* *}(0.00259)$ & MFI_size & $0.000179(0.00536)$ \\
MFI_Satudum & $-0.0333^{* *}(0.0106)$ & MFI_Satudum & $-0.0362^{* * *}(0.0106)$ \\
RL & $0.0314(0.0224)$ & RL & $0.0383^{*}(0.0227)$ \\
age_dum & $0.0201^{* *}(0.0102)$ & age_dum & $0.0199^{* *}(0.0101)$ \\
Constant & $-0.130^{* * *}(0.0406)$ & Constant & $-0.110^{* *}(0.0427)$ \\
Observations & 808 & Observations & 808 \\
R-squared & 0.25 & R-squared & 0.29 \\
\hline
\end{tabular}

Standard errors in parentheses

${ }^{* * *} p<0.01,{ }^{* *} p<0.05,{ }^{*} p<0.1$

The results are partly consistent with competitionstability theory whereby in a competitive market firm becomes both financially sustainable and socially responsible. In support of this theory, the result reveals that competition strongly and positively moderates the relationship between the depth of outreach and financial performance.

\section{Conclusions}

This paper investigates the moderating effect of competition on the relationship between social and financial performances of MFIs. To examine the moderating effect of competition, first, the relationship between social and financial performance was tested. The main finding of the study indicates that social and financial performances have a positive significant relationship. When MFIs enhance their social performance by reaching out to the poor people, it boosts their profitability and sustainability.

Besides, the finding also shows that OSS and breadth of outreach have a positive significant led and lag form of relationship. Thus, MFIs' previous year breadth of outreach affects this year's financial performance. Similarly, MFIs' previous year's profitability also positively related to the following year's breadth of outreach. But the relationship between operational self-sufficiency and depth of outreach is neither lag nor led rather cotemporal.

Moreover, competition measured by the Boone indicator reveals that during the 2005-2014 periods, the Indian microfinance market was very competitive. Surprisingly, the findings suggest that competition positively moderates the relationship between the depth of outreach and operational self-sufficiency. It appears that the association between MFIs' depth of outreach and operational self-sufficiency is conditional upon competition. Therefore, in a competitive market, the more MFIs deepen their depth of outreach, the higher the contribution it has to their operational self-sufficiency. Competition spurring MFIs to reach out to the very poor segment of the population and helps them to be sustainable.

Furthermore, the study further supports the idea that competition doesn't make MFIs to drift from its mission of serving poor people.

Therefore, the estimated results might allow this researcher to provide the following recommendations: first, to deepen financial outreach to the poor people, countries need to initiate and encouraging competition in their microfinance market. Along with this, policy regulators also need to design a policy framework that creates a sound competitive microfinance market. Second, to ensure a positive effect of competition, countries need to establish the institutional system that supervises and regulates the competition undergoing in the microfinance sector. Third, MFIs may consider social objective as a competitive advantage to be financial sustainability in the log-run.

In general, this paper finds robust results that competition moderates the link between social and financial performances. Therefore, this study may pave the way for upcoming empirical studies in microfinance on the moderating effect of competition on MFIs' performance.

\section{Practical implications for MFIs}

The results bring some implications that might be useful to academics and policymakers as well as practitioners in the field. First, the positive relationship between social and financial performance suggests that although being a socially responsible institution has a financial cost, in the long-run, it positively contributes to financial performance through retain customers and increases sales volume. Second, a competitive financial system spurring MFIs to reach out to the unbanked segment of the population. Hence, competition doesn't make MFIs to drift from their mission. It indicates that competition helps borrowers to have financial accesses and MFIs to be financially sustainable by widening the base and applying the innovative lending methodology. Third, the results show that providing financial services to the poor at an affordable price is the fundamental social responsibility that implant accountability and transparency into the microfinance sector. Last but not least, the social mission is an integral part of the microfinance sector that helps them to be financially self-sufficient. 


\section{Appendix}

Table 9 Lags and Led analysis

\begin{tabular}{lllll}
\hline Variables & (lag) & (Led) & $($ Lag) & (Led) \\
& OSS & OSS & ROA & $0.0145(0.00935)$ \\
\hline InNAB & $0.0339^{*}(0.0190)$ & $0.0425^{*}(0.0245)$ & $0.00946(0.00642)$ & $0.213^{* *}(0.0896)$ \\
depth & $-0.122(0.217)$ & $0.195(0.253)$ & $0.0772(0.0704)$ & $0.0616^{* * *}(0.00867)$ \\
MFI_size & $0.130^{* * *}(0.0222)$ & $0.140^{* *}(0.0208)$ & $0.0491^{* * *}(0.00758)$ & $0.167^{* * *}(0.0263)$ \\
RL & $0.393^{* * *}(0.0696)$ & $0.132^{*}(0.0717)$ & $0.227^{* * *}(0.0228)$ & $0.0135(0.00919)$ \\
age_dum & $-0.0199(0.0275)$ & $0.0266(0.0288)$ & $0.00358(0.00897)$ & $-1.150^{* * *}(0.0909)$ \\
Constant & $-1.410^{* * *}(0.282)$ & $-1.448^{* * *}(0.243)$ & $-0.968^{* * *}(0.0940)$ & 648 \\
Observations & 734 & 727 & 714 & 0.289 \\
R-squared & 0.213 & 0.241 & & 0.297 \\
\hline
\end{tabular}

Table 10 GMM model test

\begin{tabular}{ll}
\hline Sargan test & overid. restrictions: chi2 $(17)=40.89$ Prob $>$ chi2 $=0.001$ \\
Hansen test: excluding & Prob $>$ chi2 $=0.302$ \\
null $\mathrm{H}=$ exogenous & Prob $>$ chi2 $=0.688$ \\
Arellano-Bond & Pr $>\mathrm{z}=0.000$ \\
Hansen test & overid. Restrictions: Prob $>$ chi2 $=0.524$ \\
\hline
\end{tabular}




\section{Acknowledgements}

In presenting this review, I would like to express my gratitude to my collegues for their helpful ideas, and kind responses to my questions during the entire phases of my study.

\section{Author's contributions}

Hailu Abebe Wondirad is a corresponding author who major wrote the manuscript. The author(s) read and approved the final manuscript.

\section{Funding}

Not applicable.

\section{Availability of data and materials}

The data that support the findings of this study are available from the corresponding author upon reasonable request.

\section{Competing interests}

The authors declare that they have no competing interests

\section{Received: 9 October 2019 Accepted: 13 July 2020}

Published online: 24 October 2020

\section{References}

Ackoff, R. (1970). A concept of corporate planning. Long Range Planning, 3(1), 2-8.

Adhikary, S., \& Papachristou, G. (2014). Is there a trade-off between financial performance and outreach in South Asian microfinance institutions? The Journal of Developing Areas, 48(4), 381-402.

Amir, R. (2003). Market structure, scale economies and industry performance. In cale economies and industry performance (September 1, 2003).

Armendáriz, B., \& Szafarz, A. (2009). Microfinance mission drift. Brussels: Research Institute in Management sciences.

Assefa, E., Hermes, N., \& Meesters, A. (2013). Competition and the performance of microfinance institutions. Applied Financial Economics, 23(9), 767-782.

Baltagi, B. H. (1995). Econometric analysis of panel data, (vol. 2). New York: Wiley.

Barnett, M. L., \& Salomon, R. M. (2012). Does it pay to be really good? Addressing the shape of the relationship between social and financial performance. Strategic Management Journal, 33(11), 1304-1320.

Baron, R. M., \& Kenny, D. A. (1986). The moderator-mediator variable distinction in social psychological research: Conceptual, strategic, and statistical considerations. Journal of Personality and Social Psychology, 51(6), 1173.

Bassem, B. S. (2012). Social and financial performance of microfinance institutions: Is there a trade-off? Journal of Economics and International Finance, 4(4), 92

Bateman, M. (2010). Why microfinance doesn't work? The destructive rise of local neoliberalism. London: New York, Zed.

Battese, G. E., \& Coelli, T. J. (1992). Frontier production functions, technical efficiency and panel data: with application to paddy farmers in India. Journal of productivity analysis, 3(1-2), 153-169.

Beck, T. (2008). Bank competition and financial stability: Friends or foes? In World Bank Policy Research Working Paper Series, vol.

Bédécarrats, F., Baur, S., \& Lapenu, C. (2012). Combining social and financial performance: A paradox? Enterprise Development and Microfinance, 23(3), 241-258.

Beisland, L. A., D'Espallier, B., \& Mersland, R. (2019). The commercialization of the microfinance industry: Is there a 'personal mission drift'among credit officers? Journal of Business Ethics, 158(1), 119-134.

Boone, J. (2008). A new way to measure competition. The Economic Journal 118(531), 1245-1261.

Boyd, J. H., \& De Nicolo, G. (2005). The theory of bank risk taking and competition revisited. The Journal of Finance, 60(3), 1329-1343.

Burgess, R., \& Pande, R. (2003). Do rural banks matter. In Evidence from the Indian social banking experiment. Evidence from the Indian social banking experiment (August 2003).

Carletti, E., \& Hartmann, P. (2002). Competition and stability: What's special about banking?

Coccorese, P. (2009). Market power in local banking monopolies. Journal of Banking \& Finance, 33(7), 1196-1210

Conning, J. (1999). Outreach, sustainability and leverage in monitored and peermonitored lending. Journal of Development Economics, 60(1), 51-77.

Cornell, B., \& Shapiro, A. C. (1987). Corporate stakeholders and corporate finance. Financial Management, 16(1), 5-14.
Cull, R., Demirgüç-Kunt, A., \& Morduch, J. (2008). Microfinance meets the market. In World Bank Policy Research Working Paper Series.

Cull, R., Demirgüç-Kunt, A., \& Morduch, J. (2009). Microfinance meets the market. Journal of Economic Perspectives, 23(1), 1-30.

Cull, R., Demirgüç-Kunt, A., \& Morduch, J. (2011). Does regulatory supervision curtail microfinance profitability and outreach? World Development, 39(6), 949-965.

D’Espallier, B., Goedecke, J., Hudon, M., \& Mersland, R. (2017). From NGOs to banks: Does institutional transformation alter the business model of microfinance institutions? World Development, 89, 19-33.

Datta, R. (2003). From development to empowerment: the self employed women's Association in India. International Journal of Politics, Culture and Society, 16(3), 351-368.

Delis, M., losifidi, M., \& Tsionas, E. G. (2014). On the estimation of marginal cost. Operations Research, 62(3), 543-556.

Dick, A. A. (2007). Market size, service quality, and competition in banking. Journal of Money, Credit and Banking, 39(1), 49-81.

Etzensperger, C. (2013). Microfinance market outlook 2014: No 'sudden stop': Demand for microfinance soars. Zurich: ResponsAbility Investment AG.

Fombrun, C. J., Gardberg, N. A., \& Barnett, M. L. (2000). Opportunity platforms and safety nets: Corporate citizenship and reputational risk. Business and Society Review, 105(1), 85-106.

Freeman, R. E. (2010). Strategic management: A stakeholder approach. Cambridge: University Press.

Friedman, M. (1970). A Friedman doctrine: The social responsibility of business is to increase its profits. The New York Times Magazine, 13(1970), 32-33.

Ghate, P. (2007). Indian Microfinance: The challenges of rapid growth. SAGE Publications India.

Gonzalez, A. (2010). Microfinance Synergies and Trade-offs: Social versus Financial Performance Outcomes in 2008. MIX Data Brief No. 7. Washington, D.C.: MIX August.

Greene, W. H. (2008). The econometric approach to efficiency analysis. In The measurement of productive efficiency and productivity growth, 92-250.

Greening, D. W., \& Turban, D. B. (1996). Corporate Social Performance and Organizational Attractiveness to Prospective Employees. In Proceedings of the International Association for Business and Society, (vol. 7, pp. 489-500).

Guha, B., \& Chowdhury, P. R. (2014). Borrower targeting under microfinance competition with motivated microfinance institutions and strategic complementarity. The Developing Economies, 52(3), 211-240.

Guha, M. (2013). Are microfinance services relevant for micro-entrepreneurial growth: a case based discussion from Indian microfinance models. In Paper accepted for presentation at 4th international conference on Institutional and Technological Environment for Microfinance (ITEM4), Paris.

Guha, S. (2007). Impact of competition on microfinance beneficiaries: Evidence from India.

Gutierrez-Nieto, B., Serrano-Cinca, C., \& Molinero, C. M. (2007). Microfinance institutions and efficiency. Omega, 35(2), 131-142.

Gutiérrez-Nieto, B., Serrano-Cinca, C., \& Molinero, C. M. (2009). Social efficiency in microfinance institutions. Journal of the Operational Research Society, 104-119.

Helms, B., \& Reille, X. (2004). Interest rate ceilings and microfinance: The story so far (No. 33479, pp. 1-20). The World Bank.

Hermes, N., Lensink, R., \& Meesters, A. (2011). Outreach and efficiency of microfinance institutions. World Development, 39(6), 938-948.

Hudon, M. (2011). Ethics in microfinance. In B. Armendariz, \& M. Labie (Eds.), The handbook of microfinance, (pp. 123-138). London-Singapore: Scientific Work.

Kanwal, M., Khanam, F., Nasreen, S., \& Hameed, S. (2013). Impact of corporate social responsibility on the firm's financial performance. Journal of Business and Management, 14(5), 67-74.

Kar, A. K. (2016). Measuring competition in microfinance markets: A new approach. International Review of Applied Economics, 30(4), 423-440.

Khanam, D., Parvin, S. S., Mohiuddin, M., Hoque, A., \& Su, Z. (2018). Financial sustainability of non-governmental microfinance institutions (MFIs): A costefficiency analysis of BRAC, ASA, and PROSHIKA from Bangladesh. Review of Economics \& Finance, 12(2), 43-56.

Klein, J., \& Dawar, N. (2004). Corporate social responsibility and consumers' attributions and brand evaluations in a product-harm crisis. International Journal of Research in Marketing, 21(3), 203-217.

Lapenu, C. (2007). What microfinance for agriculture in developing countries. In Document prepared by the French Microfinance Network Rural Finance Commission.

Lau, L. J. (1982). On identifying the degree of competitiveness from industry price and output data. Economics Letters, 10(1), 93-99. 
Lebovics, M., Hermes, N., \& Hudon, M. (2016). Are financial and social efficiency mutually exclusive? A case study of Vietnamese microfinance institutions. Annals of Public and cooperative Economics, 87(1), 55-77.

Ledgerwood, J. (1999). Sustainable banking with the poor microfinance handbook.

Littlefield, E. L., \& Kneiding, C. (2009). The global financial crisis and its impact on microfinance (No. 47954, pp. 1-8). Washington, DC: The World Bank.

Mader, P. (2013). Rise and Fall of Microfinance in India: The Andhra Pradesh Crisis in Perspective. Strategic Change, 22(1-2), 47-66.

Maes, J. P., \& Reed, L. R. (2012). State of the microcredit summit campaign report 2012. Washington, DC: Microcredit Summit Campaign.

Maîtrot, M. (2019). Understanding social performance: A 'practice drift'at the frontline of microfinance institutions in Bangladesh. Development and Change, 50(3), 623-654.

Mclntosh, C., Janvry, A., \& Sadoulet, E. (2005). How rising competition among microfinance institutions affects incumbent lenders*. The Economic Journal, 115(506), 987-1004.

McIntosh, C., \& Wydick, B. (2005). Competition and microfinance. Journal of Development Economics, 78(2), 271-298.

Mersland, R. (2011). The governance of non-profit micro finance institutions: Lessons from history. Journal of Management \& Governance, 15(3), 327-348.

Mersland, R., \& Strøm, R. Ø. (2009). Performance and governance in microfinance institutions. Journal of Banking \& Finance, 33(4), 662-669.

Mersland, R., \& Strøm, R. Ø. (2010). Microfinance mission drift? World Development, 38(1), 28-36.

Montgomery, H., \& Weiss, J. (2011). Can commercially-oriented microfinance help meet the millennium development goals? Evidence from Pakistan. World Development, 39(1), 87-109.

Morduch, J. (1999). The microfinance promise. Journal of Economic Literature, 37(4), 1569-1614.

Morduch, J. (2000). The microfinance schism. World Development, 28(4), 617-629.

Motta, M. (2004). Competition policy: Theory and practice. Cambridge: University Press.

Navajas, S., Conning, J., \& Gonzalez-Vega, C. (2003). Lending technologies, competition and consolidation in the market for microfinance in Bolivia. Journal of International Development, 15(6), 747-770.

Navajas, S., Schreiner, M., Meyer, R. L., Gonzalez-Vega, C., \& Rodriguez-Meza, J. (2000). Microcredit and the poorest of the poor: Theory and evidence from Bolivia. World Development, 28(2), 333-346.

Nawaz, A., \& Iqbal, S. (2015). Financial performance and corporate governance in microfinance: Who drives who? An evidence from Asia.

Ngo, T. V. (2015). Microfinance complementarity and trade-off between financia performance and social impact. International Journal of Economics and Finance, $7(11), 128$.

Olsen, T. D. (2010). New actors in microfinance lending: The role of regulation and competition in Latin America. Perspectives on Global Development and Technology, 9(3), 500-519.

Orlitzky, M., \& Benjamin, J. D. (2001). Corporate social performance and firm risk: A meta-analytic review. Business \& Society, 40(4), 369-396.

Panzar, J. C., \& Rosse, J. N. (1987). Testing for "monopoly" equilibrium. The Journal of Industrial Economics, 35(4), 443-456.

Porteous, D. (2006). Competition and interest rates in microfinance. (no. 33) Washington DC: CGAP Focus Note.

Preston, L. E., \& O'bannon, D. P. (1997). The corporate social-financial performance relationship. Business and Society, 36(4), 419

Quayes, S. (2012). Depth of outreach and financial sustainability of microfinance institutions. Applied Economics, 44(26), 3421-3433.

Ribstein, L. E. (2005). Accountability and responsibility in corporate governance. Notre Dame L.Rev., 81, 1431.

Robinson, M. S. (2001). The microfinance revolution: Sustainable finance for the poor. Washington, DC:: The World Bank.

Rosenberg, R., Gonzalez, A., \& Narain, S. (2009). Are microcredit interest rates excessive? CGAP brief.

Ruf, B. M., Muralidhar, K., Brown, R. M., Janney, J. J., \& Paul, K. (2001). An empirical investigation of the relationship between change in corporate social performance and financial performance: A stakeholder theory perspective. Journal of Business Ethics, 32(2), 143-156.

Schaeck, K., \& Čihák, M. (2008). How does competition affect efficiency and soundness in banking? New empirical evidence.

Schicks, J., \& Rosenberg, R. (2011). Too much microcredit?: A survey of issues and evidence on over-indebtedness among micro-borrowers. In CGAP occasional paper.
Schreiner, M. (2002). Aspects of outreach: A framework for discussion of the social benefits of microfinance. Journal of International Development, 14(5), 591-603.

Servet, J. (2011). Corporate responsibility versus social performance and financial inclusion. In The handbook of microfinance, (pp. 301-322). Singapore: World Scientific.

Shah, M., Rao, R., \& Shankar, P. V. (2007). Rural credit in 20th century India: Overview of history and perspectives. Economic and Political Weekly, 42(15), 1351-1364.

Sharma, A. (2006). Microfinance: Hope for the Poor, (vol. 100, p. 31). DELHI: YOJANA.

Simpson, W. G., \& Kohers, T. (2002). The link between corporate social and financial performance: Evidence from the banking industry. Journal of Business Ethics, 35(2), 97-109.

Taylor, M. (2011). 'Freedom from poverty is not for free': Rural development and the microfinance crisis in Andhra Pradesh, India. Journal of Agrarian Change, 11(4), 484-504

Van Leuvensteijn, M., Bikker, J. A., van Rixtel, A. A., \& Sørensen, C. K. (2011). A new approach to measuring competition in the loan markets of the euro area. Applied Economics, 43(23), 3155-3167.

Vance, S. C. (1975). Are socially responsible corporations good investment risks. Management Review, 64(8), 19-24.

Vanroose, A., \& D'Espallier, B. (2013). Do microfinance institutions accomplish thei mission? Evidence from the relationship between traditional financial sector development and microfinance institutions' outreach and performance. Applied Economics, 45(15), 1965-1982.

Villas-Boas, J. M., \& Schmidt-Mohr, U. (1999). Oligopoly with asymmetric information: Differentiation in credit markets. The Rand Journal of Economics, 30(3), 375-396

Vogelgesang, U. (2003). Microfinance in times of crisis: The effects of competition rising indebtedness, and economic crisis on repayment behavior. World Development, 31(12), 2085-2114.

Wichterich, C. (2012). The Other Financial Crisis: Growth and crash of the microfinance sector in India. Development, 55(3), 406-412.

Woller, G. (2002). The promise and peril of microfinance commercialization. Small Enterprise Development, 13(4), 12-21.

\section{Publisher's Note}

Springer Nature remains neutral with regard to jurisdictional claims in published maps and institutional affiliations.

\section{Submit your manuscript to a SpringerOpen ${ }^{\circ}$ journal and benefit from:}

- Convenient online submission

- Rigorous peer review

- Open access: articles freely available online

- High visibility within the field

- Retaining the copyright to your article

Submit your next manuscript at $\boldsymbol{\nabla}$ springeropen.com 